\title{
Phylogeny, biogeography, and evolution of two Mediterranean snakes, Malpolon monspessulanus and Hemorrhois hippocrepis (Squamata, Colubridae), using mtDNA sequences
}

\author{
S. Carranza ${ }^{\mathrm{a}, *}$, E.N. Arnold ${ }^{\mathrm{b}}$, J.M. Pleguezuelos ${ }^{\mathrm{c}}$ \\ a Departament de Biologia Animal, Universitat de Barcelona, Av. Diagonal 645, E-08028 Barcelona, Spain \\ ${ }^{\mathrm{b}}$ Department of Zoology, The Natural History Museum, London SW7 5BD, UK \\ ${ }^{c}$ Departamento de Biología Animal y Ecologia, Facultad de Ciencias, Universidad de Granada, E-18071 Granada, Spain
}

Received 4 October 2005; revised 20 March 2006; accepted 22 March 2006

Available online 28 March 2006

\begin{abstract}
Variation in $815 \mathrm{bp}$ of mitochondrial DNA from two gene fragments (300 bp of cytochrome $b$ and $395-515$ bp of $12 \mathrm{~S}$ rRNA) for 26 Malpolon monspessulanus, and cytochrome $b$ for a further 21 individuals, indicates that this species originated in the Maghreb area of Northwest Africa. Here, an estimated 3.5-6 Mya, it divided into the western M. m. monspessulanus, and an eastern clade including M. m. insignitus and M. m. fuscus. The very limited genetic differentiation between Maghreb and Southwest European populations of this form suggests that it arrived in the Iberian Peninsula only recently. Population genetics and demographic tests indicate subsequent expansion in this area around 83,000-168,000 year ago. Because present populations of Malpolon arrived recently, mid-Pliocene and at least some Pleistocene fossils of the genus Malpolon in Southwest Europe are probably derived from an earlier invasion from the Maghreb, possibly as early as the end of the Miocene period, 5.3-5.9 Mya, when there was a temporary land bridge across the site of the Strait of Gibraltar and the Mediterranean Sea desiccated. The descendants of this earlier invasion must have eventually become extinct, perhaps during one of the Pleistocene glaciations. In contrast to the western $M$. m. monspessulanus, the greater genetic divergence found in the eastern clade of $M$. monspessulanus suggests that it dispersed at an earlier date and probably over a longer period, spreading eastwards through northern Libya and Egypt to Syria, Iraq, and Iran, and around the Mediterranean Sea through Turkey into the Aegean archipelagos and the Balkan peninsula. The western and eastern units of M. monspessulanus have different dorsal color pattern, differences in skull structure and exhibit an $8.4 \%$ uncorrected genetic divergence in the combined gene fragments investigated here. It is consequently recommended that they should be treated as separate species: M. monspessulanus (sensu stricto) and Malpolon insignitus stat. nov., the latter including the subspecies Malpolon insignitus fuscus comb. nov. The same combined mitochondrial gene fragments used in Malpolon were investigated in 20 individuals of Hemorrhois hippocrepis, and of cytochrome $b$ alone in a further 17. They indicate that this species also originated in the Maghreb and again invaded the Iberian Peninsula quite recently. Some of the most recent invasions of the Iberian Peninsula by reptiles and amphibian taxa could probably be anthropogenic in origin. Some other species including $M$. monspessulanus and H. hippocrepis, may have crossed naturally, by 'hopping' across the Strait of Gibraltar via temporary islands on the shallowest parts that were exposed during sea-level fall associated with Pleistocene glaciations.
\end{abstract}

(C) 2006 Elsevier Inc. All rights reserved.

Keywords: Malpolon; Hemorrhois; Phylogeography; Continental invasion; Strait of Gibraltar; Camarinal Sill; Cytochrome $b$; 12S rRNA

\footnotetext{
${ }^{*}$ Corresponding author. Fax: +34934035740.

E-mail addresses: scarranza@ub.edu (S. Carranza), ena@nhm.ac.uk (E.N. Arnold), juanple@ugr.es (J.M. Pleguezuelos).
}

\section{Introduction}

At the western end of the Mediterranean, there has been considerable movement of reptile and amphibian lineages between the Iberian Peninsula of Southwest Europe and the Maghreb area of Northwest Africa, which comprises 
Morocco, northern Algeria, and Tunisia. Much of this migration has been southwards into the Maghreb, with several instances probably occurring during the Messinian period, 5.3-5.9 Mya, when a land connection briefly developed between the two areas at the site of the present Strait of Gibraltar, causing the Mediterranean Sea to desiccate (Duggen et al., 2003; Hsü et al., 1977, 1973; Krijgsman et al., 1999). Such cases involve considerable genetic differentiation between related Iberian and Maghreb taxa and include sharp-ribbed newts (Pleurodeles) (Carranza and Arnold, 2004; Carranza and Wade, 2004), discoglossid frogs (Discoglossus and Alytes) (Arntzen and Garcia-Paris, 1995; Fromhage et al., 2004; García-París and Jockusch, 1999; Martínez-Solano, 2004; Martínez-Solano et al., 2004), spadefoot toads (Pelobates) (García-París et al., 2003), typical frogs (Rana) (Plötner, 1998), fire-salamanders (Salamandra) (Escoriza et al., in press), and possibly one lineage of the Podarcis hispanica group of lacertid lizards (Pinho et al., 2006). A lesser though still marked genetic differentiation suggests that some southward migrations were more recent, occurring after the collapse of the Gibraltar land bridge and the subsequent refilling of the Mediterranean Sea from the Atlantic. They are consequently likely to have been across water rather than land and include at least one lineage of $P$. hispanica (Harris et al., 2002) and the lacertid lizard Psammodromus algirus (Carranza et al., in press). Very recent southward migrations (resulting in no overt differentiation in the mitochondrial gene fragments investigated so far) include the terrapins Emys orbicularis (Lenk et al., 1999) and Mauremys caspica (Busack, 1986; Fritz et al., 2005), and a second colonization by the newt Pleurodeles (Batista et al., 2004; Carranza and Arnold, 2004). Northward migration associated with marked genetic differentiation was less common but appears to have occurred in the Messinian in at least one lineage of Chalcides skinks (Carranza and Arnold, unpublished data) and in the lacertid lizard Acanthodactylus erythrurus (Harris et al., 2004). Virtual absence of differentiation in mitochondrial DNA suggests that other northward colonizations of the Iberian Peninsula by Maghreb species were much more recent. They include a tortoise, Testudo graeca (Álvarez et al., 2000), a false smooth snake, Macroprotodon brevis ibericus (Carranza et al., 2004), a tree frog, Hyla meridionalis (Busack, 1986), and a chameleon, Chamaeleo chamaeleon, which may have arrived twice (Paulo et al., 2002).

All the groups studied so far that have moved between the Maghreb and Iberia have relatively small body sizes. Here, we investigate two large colubrid snakes, the Montpellier snake, Malpolon monspessulanus (Hermann, 1804), and the Horseshoe whip-snake, H. hippocrepis (Linnaeus, 1758). M. monspessulanus may grow to $200 \mathrm{~cm}$ and a weight of $1.5 \mathrm{~kg}$, and is distributed in Mediterranean habitats almost right around this sea, being absent only from most of Italy. Morphology indicates that its closest relative is the only other species assigned to Malpolon: $M$. moilensis.
Three subspecies are currently recognised (De Haan, 1999). Malpolon m. monspessulanus occurs in Southwest Europe and the western Maghreb, where it is found in Morocco and coastal Algeria as far east as Algiers. It usually has 19 dorsal scale rows at mid-body, and males have a dark 'saddle' on the foreparts. Malpolon monspessulanus insignitus ranges from east Morocco through Algeria and Tunisia eastwards around the Mediterranean Sea to western Syria. It again usually has 19 dorsal scale rows at mid-body but no 'saddle' is present in males, and colouring often includes narrow longitudinal pale stripes. In east Morocco and west Algeria it replaces M. m. monspessulanus away from the coast, on the high plateau, so the two subspecies overlap longitudinally but not latitudinally for several $100 \mathrm{~km}$. M. monspessulanus fuscus, which occurs in Turkey and Southeast Europe and eastwards through north Iraq and western Iran, differs from $M$. m. insignitus in regularly having 17 dorsal scale rows at mid-body. Populations in some areas in the east of the range of M. monspessulanus cannot be clearly assigned to either $M$. $m$. insignitus or $M$. m. fuscus, those from the more arid parts of Syria, Jordan, and Iraq having either 17 or 19 scale rows. Differences in skull structure have also been reported between western and eastern populations of M. monspessulanus (Szyndlar, 1988).

Hemorrhois hippocrepis may grow to $185 \mathrm{~cm}$ and also occurs in Mediterranean habitats, but it has a much more restricted distribution than $M$. monspessulanus, being confined to the Maghreb, the southern two-thirds of the Iberian Peninsula and the Mediterranean islands of Sardinia, Zembreta, and Pantellaria (see Fig. 1). The population on the last island is regarded as a separate subspecies, H. h. nigrescens (Cattaneo, 1985). The closest relative of $H$. hippocrepis is $H$. algirus, which occurs in drier areas of the Maghreb (Utiger, 2002).

Malpolon monspessulanus and $H$. hippocrepis are mainly diurnal snakes (although, H. hippocrepis may sometimes be found active at dusk and at night in warm weather. They play important roles in Iberian and Maghreb reptile communities (Feriche, 1998; Pleguezuelos, 1998a,b; Pleguezuelos and Fahd, 2004). They are both significant prey items for many vertebrate predators including raptors, and they eat a wide range of smaller vertebrates, especially lizards in the case of M. monspessulanus and mammals in H. hippocrepis (Pleguezuelos, 1998a,b). Malpolon has an extensive fossil record in Southwest Europe dating back to the mid-Pliocene (Bailón, 1991; Balin, 2005; Barroso and Bailón, 2003; Gleed-Owen, 2001; Szyndlar, 1988, 1991). Much of the fossil material consists of vertebrae, which are difficult to assign to species, but a partial brain case from a mid-Pliocene site at Layna, northeast Spain has been assigned to a new taxon, M. mlynarskii (Szyndlar, 1988). A basiparasphenoid bone of about the same age from Sète, Mediterranean France agrees with that of M. monspessulanus itself (Bailón, 1991). Relatively long presence of Malpolon in North Africa is also supported by fossils, from the uppermost Pliocene of Casa Blanca, Morocco (Bailón, 

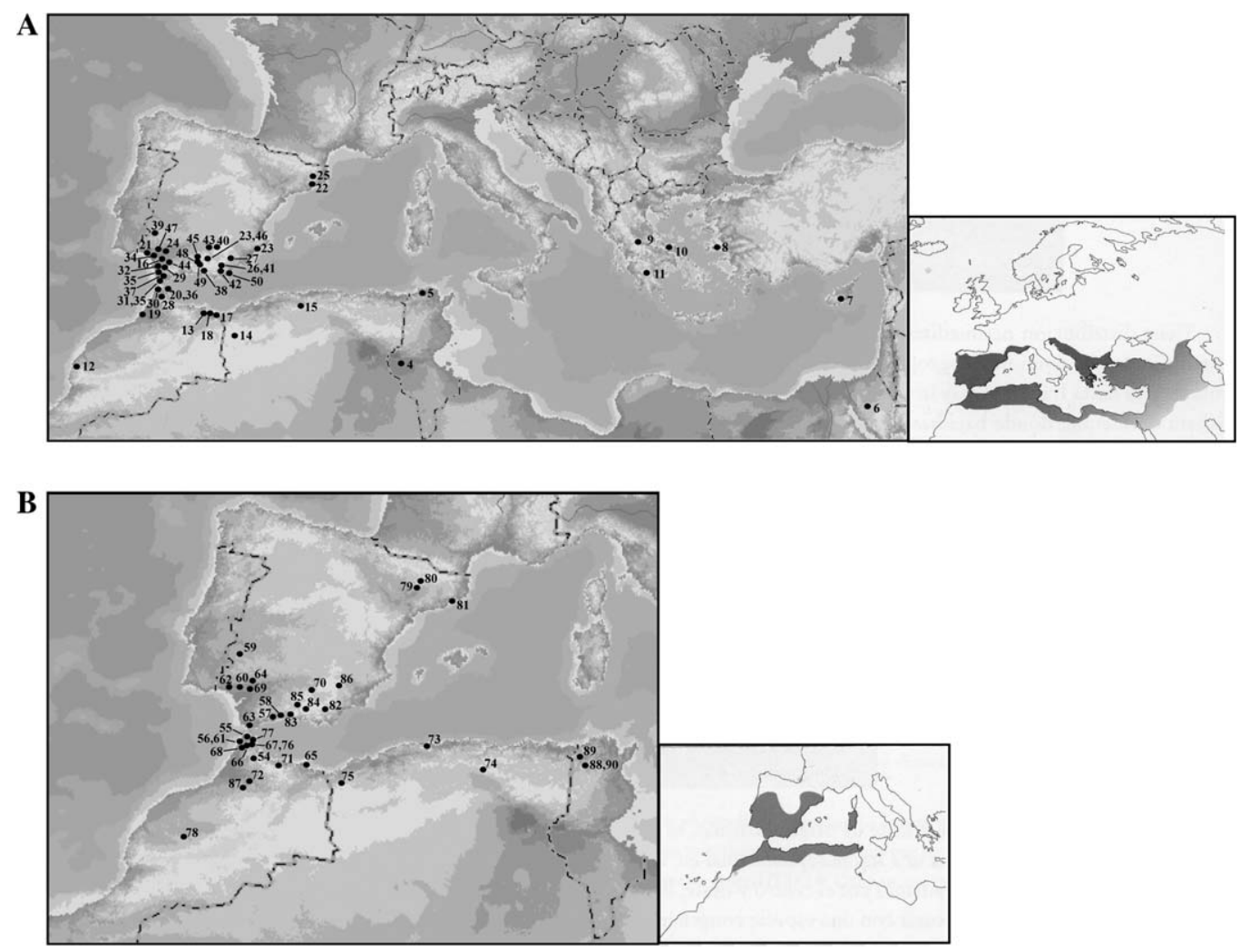

Fig. 1. Maps showing all sampling localities and geographic distributions of Malpolon monspessulanus (A) and Hemorrhois hippocrepis (B). Numbers refer to specimen codes in Table 1. Vignettes show total distribution of the species.

2000). However, in spite of long occurrence of Malpolon in both areas, there is no overt morphological differentiation between living populations assigned to M. monspessulanus in Southwest Europe and those in the Maghreb. Similarly, allozyme studies (Busack, 1986) show little differentiation between the two regions. This suggests that there has been recent movement from one region to the other, the invading population perhaps replacing whatever was there before.

In contrast to $M$. monspessulanus, H. hippocrepis has a poor fossil record extending no further back than the late-Pleistocene in Spain (Bailón, 1986; López-Martínez and Sanchiz, 1981). But like this species, it lacks morphological differentiation across the Strait of Gibraltar. Some previous molecular data indicate that its close relatives have a North African origin (Nagy et al., 2004; Utiger, 2002; Utiger et al., 2002), which would suggest that the same applies to $H$. hippocrepis itself and that it dispersed from here to the Iberian Peninsula.

We present mitochondrial DNA sequence data and analyses to clarify the uncertainties about the biogeography of $M$. monspessulanus and H. hippocrepis. In particular, an attempt is made to determine their general areas of origin and direction of movement between the Maghreb and Southwest Europe. Movement of M. monspessulanus around the eastern Mediterranean is also examined as well as its taxonomy. This is accomplished by initially using $300 \mathrm{bp}$ of cytochrome $b$ and 395-515 bp of 12S rRNA, and then employing cytochrome $b$ alone for additional specimens to increase sample size.

\section{Materials and methods}

\subsection{Samples, DNA extraction, and amplification}

A total of 88 snakes were used in this study: 39 Malpolon monspessulanus monspessulanus, four M. m. insignitus, four M. m. fuscus, and $37 \mathrm{H}$. hippocrepis, with one $\mathrm{H}$. algirus, one M. moilensis, and two Psammophis schokari as outgroups. Localities and specimen codes for these animals, and GenBank accession number for the gene fragments analyzed are listed in Table 1; the localities are shown in Fig. 1. A few of the tissue samples were obtained from museum specimens, and museum accession number are also given for these (see Table 1). Most of the remaining samples for DNA analyses were obtained from road-kills that could be identified to species level, and live specimens, which were immediately released were caught. Fragments of the mitochondrial genes cytochrome $b$ (cytb) and $12 \mathrm{~S}$ rRNA (12S) were amplified and sequenced using standard PCR conditions and methods described elsewhere (Carranza et al., 1999, 2000). Primers employed in both amplification and sequencing were CB1 and CB2 for the cytb gene (Palumbi, 1996) and 12Sa and 12Sb (Kocher et al., 1989) and 12S268 and 12S916 (Utiger, 2002; Utiger et al., 2002) for the $12 \mathrm{~S}$ rRNA. 
Table 1

Details of material and sequences used in the present study

\begin{tabular}{|c|c|c|c|c|}
\hline Taxa & $\begin{array}{l}\text { Specimen code } \\
\text { (Fig. 1) }\end{array}$ & Locality & $\begin{array}{l}\text { GenBank Accession Nos. } \\
\text { cytb/12S }\end{array}$ & Working code \\
\hline Psammophis schokari & 1 & Oulad Mohamed (Morocco) & AY643398/AY643314 & E1110.31 \\
\hline Psammophis schokari & 2 & S. of Berkane (Morocco) & DQ451879/DQ451926 & E1110.32 \\
\hline Malpolon moilensis & 3 & Biskra (Algeria) & AY643397/AY643313 & E1110.16 \\
\hline Malpolon m. insignitus & 4 & Tozeur city (Tunisia) & DQ451886/DQ451950 & E2509.14 \\
\hline Malpolon m. insignitus & 5 & Tabarka T31-20 (Tunisia) & DQ451885/DQ451949 & E2509.13 \\
\hline Malpolon m. insignitus & 6 & El Cairo (Egypt) & DQ451887/DQ451951 & E14053.4 \\
\hline Malpolon m. insignitus & 7 & Vrysoulles (Cyprus) & DQ451884/DQ451948 & E14053.3 \\
\hline Malpolon m. fuscus & 8 & Khíos (Chios) island (Greece) NHMC 80.3.24.10 & DQ451883/DQ451947 & E14053.5 \\
\hline Malpolon m. fuscus & 9 & Prefecture of Evritania (Greece) NHMC 80.3.24.7 & DQ451882/DQ451946 & E14053.8 \\
\hline Malpolon m. fuscus & 10 & Kimih island of Eyvoia (Greece) NHMC 80.3.24.4 & DQ451880/DQ451944 & E14053.6 \\
\hline Malpolon m. fuscus & 11 & Kletoria Lake, Peloponnisios (Greece) NHMC 80.3.24.6 & DQ451881/DQ451945 & E14053.7 \\
\hline Malpolon m. monspessulanus & 12 & Essaouira (Morocco) & DQ451925/DQ451943 & $\mathrm{E} 2509.17$ \\
\hline Malpolon m. monspessulanus & 13 & $8 \mathrm{~km} \mathrm{~W}$. of Ras el Ma, Melilla (Morocco) & DQ451922/DQ451934 & E2509.16 \\
\hline Malpolon m. monspessulanus & 14 & $5 \mathrm{~km} \mathrm{~N}$. El Aouedj (Algeria) & DQ451893/DQ451942 & E9124.1 \\
\hline Malpolon m. monspessulanus & 15 & N. of Chrea (Algeria) & DQ451919/DQ451932 & E9124.2 \\
\hline Malpolon m. monspessulanus & 16 & Marismas del Guadalquivir (Spain) & DQ451892/DQ451931 & E1209.5 \\
\hline Malpolon m. monspessulanus & 17 & Close to Saidia (Morocco) & DQ451902/DQ451930 & E14053.2 \\
\hline Malpolon m. monspessulanus & 18 & Ras el Ma (Morocco) & DQ451903/DQ451927 & E2509.18 \\
\hline Malpolon m. monspessulanus & 19 & N. of Kenitra (Morocco) & DQ451899/DQ451929 & E5113.13 \\
\hline Malpolon m. monspessulanus & 20 & Ceuta, NW Morocco (Spain) & DQ451920/DQ451928 & E2509.21 \\
\hline Malpolon m. monspessulanus & 21 & Huelva (Spain) & DQ451907/DQ451933 & E5121.54 \\
\hline Malpolon m. monspessulanus & 22 & Badalona (Spain) & DQ451900/DQ451939 & E14053.9 \\
\hline Malpolon m. monspessulanus & 23 & Huetor Santillan (Spain) & DQ451924/DQ451941 & E1209.4 \\
\hline Malpolon m. monspessulanus & 24 & Sevilla (Spain) & DQ451921/DQ451938 & E14053.12 \\
\hline Malpolon $\mathrm{m}$. monspessulanus & 25 & Sant Celoni (Spain) & DQ451898/Q451937 & E14053.11 \\
\hline Malpolon m. monspessulanus & 26 & San Juan de Terreros (Spain) & DQ451915/DQ451935 & E5121.45 \\
\hline Malpolon m. monspessulanus & 27 & Alboloduy, Almeria (Spain) & DQ451923/DQ451940 & E5121.50 \\
\hline Malpolon m. monspessulanus & 28 & Souk el Arba de Beni Hassan (Morocco) & AY643396/AY643312 & E2509.15 \\
\hline Malpolon m. monspessulanus & 29 & San José del Valle, Cadiz (Spain) & DQ451901/DQ451936 & E14053.10 \\
\hline Malpolon m. monspessulanus & 30 & Tanger (Morocco) & DQ451888/ & E1209.6 \\
\hline Malpolon $\mathrm{m}$. monspessulanus & 31 & Barbate (Spain) & DQ451889/ & E1209.7 \\
\hline Malpolon m. monspessulanus & 32 & Jerez de la Frontera (Spain) & DQ451890/ & E1110.18 \\
\hline Malpolon m. monspessulanus & 33 & Sierra de Retin (Spain) & DQ451891/ & E1110.19 \\
\hline Malpolon m. monspessulanus & 34 & Bodegones (Spain) & DQ451894/ & E2509.22 \\
\hline Malpolon m. monspessulanus & 35 & North of Vejer de la Frontera, Cadiz (Spain) & DQ451895/ & E1110.17 \\
\hline Malpolon $m$. monspessulanus & 36 & Ceuta (Spain) & DQ451896/ & E2509.19 \\
\hline Malpolon m. monspessulanus & 37 & Laguna de Medina, Cadiz (Spain) & DQ451897/ & E2509.20 \\
\hline Malpolon m. monspessulanus & 38 & Cara S. Sierra Nevada, Granada (Spain) & DQ451904/ & E5121.55 \\
\hline Malpolon m. monspessulanus & 39 & Barrancos/Encinasola (Spain) & DQ451905/ & E5121.56 \\
\hline Malpolon m. monspessulanus & 40 & Huesa, Jaen (Spain) & DQ451906/ & E5121.53 \\
\hline Malpolon m. monspessulanus & 41 & San Juan de los Terreros, Almeria (Spain) & DQ451908/ & E5121.51 \\
\hline Malpolon m. monspessulanus & 42 & Tabernas, Almeria (Spain) & DQ451909/ & E5121.52 \\
\hline Malpolon m. monspessulanus & 43 & Torres, Jaen (Spain) & DQ451910/ & E5121.48 \\
\hline Malpolon m. monspessulanus & 44 & Montejaque, Cadiz (Spain) & DQ451911/ & E5121.49 \\
\hline Malpolon m. monspessulanus & 45 & Chimeneas, Granada (Spain) & DQ451912/ & E5121.43 \\
\hline Malpolon m. monspessulanus & 46 & Huetor Santillan (Spain) & DQ451913/ & E1209.3 \\
\hline Malpolon m. monspessulanus & 47 & San Lucar la Mayor, Sevilla (Spain) & DQ451914/ & E5121.44 \\
\hline Malpolon m. monspessulanus & 48 & Villanueva de Tapia, Granada (Spain) & DQ451916/ & E5121.46 \\
\hline Malpolon m. monspessulanus & 49 & Venta del Fraile, Padul (Spain) & DQ451917/ & E5121.47 \\
\hline Malpolon m. monspessulanus & 50 & Rodalquiar, Almeria (Spain) & DQ451918/ & E5121.57 \\
\hline Hemorrhois algirus & 51 & Bou Chebka (Tunisia) & AY643391/AY643307 & E1110.1 \\
\hline Hemorrhois hippocrepis & 54 & Xauen (Morocco) & DQ451952/ & E512.5 \\
\hline Hemorrhois hippocrepis & 55 & Ued Aliane (Morocco) & DQ451953/ & E512.6 \\
\hline Hemorrhois hippocrepis & 56 & Kahaoucha (Morocco) & DQ451954/DQ451989 & E512.4 \\
\hline Hemorrhois hippocrepis & 57 & San Luis de Sabinillas, Cadiz (Spain) & DQ451955/ & E512.17 \\
\hline Hemorrhois hippocrepis & 58 & Arroyo de la Parrilla, Malaga (Spain) & DQ451956/ & E512.16 \\
\hline Hemorrhois hippocrepis & 59 & Valle de Matamoros (Spain) & DQ451957/ & E512.15 \\
\hline Hemorrhois hippocrepis & 60 & Bollullos, Huelva (Spain) & DQ451958/ & E512.14 \\
\hline Hemorrhois hippocrepis & 61 & Close to Kahaoucha (Morocco) & DQ451959/ & E512.1 \\
\hline Hemorrhois hippocrepis & 62 & Aljaraque, Huelva (Spain) & DQ451960/DQ451988 & E2509.7 \\
\hline Hemorrhois hippocrepis & 63 & Sierra de Enmedio, Cadiz (Spain) & DQ451961/DQ451990 & E2509.6 \\
\hline Hemorrhois hippocrepis & 64 & El Garrobo, Arroyo de la Torre, Sevilla (Spain) & DQ451962/DQ451991 & E2509.5 \\
\hline Hemorrhois hippocrepis & 65 & Ras el Ma, Morocco (Morocco) & DQ451963/DQ451992 & E2509.4 \\
\hline
\end{tabular}


Table 1 (continued)

\begin{tabular}{|c|c|c|c|c|}
\hline Taxa & $\begin{array}{l}\text { Specimen code } \\
\text { (Fig. 1) }\end{array}$ & Locality & $\begin{array}{l}\text { GenBank Accession Nos. } \\
\text { cytb/12S }\end{array}$ & Working code \\
\hline Hemorrhois hippocrepis & 66 & Beni Arouss (Morocco) & DQ451964/DQ452002 & E2509.3 \\
\hline Hemorrhois hippocrepis & 67 & $8 \mathrm{~km}$ from Zinat (Morocco) & DQ451965/DQ451993 & E2509.1 \\
\hline Hemorrhois hippocrepis & 68 & Souk-el-Arba-Ayacha (Morocco) & DQ451966/ & E1209.8 \\
\hline Hemorrhois hippocrepis & 69 & Sevilla (Spain) & DQ451967/ & E1209.14 \\
\hline Hemorrhois hippocrepis & 70 & Bedmar-Jodar, Jaen (Spain) & DQ451968/ & E1209.11 \\
\hline Hemorrhois hippocrepis & 71 & Had-Rouadi (Morocco) & DQ451969/ & E512.3 \\
\hline Hemorrhois hippocrepis & 72 & Kariah-Bab-Mohamed, 20 km N. Fez (Morocco) & DQ451970/DQ451998 & E5113.2 \\
\hline Hemorrhois hippocrepis & 73 & Sidi-Ferruch, close to Algiers (Algeria) & DQ451971/DQ451994 & E1110.5 \\
\hline Hemorrhois hippocrepis & 74 & Dj. Maadid, N. of M'sila (Algeria) & DQ451972/DQ451995 & E1110.6 \\
\hline Hemorrhois hippocrepis & 75 & Tlemcen (Algeria) & DQ451973/DQ451996 & E1110.7 \\
\hline Hemorrhois hippocrepis & 76 & $8 \mathrm{~km}$ from Zinat (Morocco) & AY643392/AY643308 & E2509.2 \\
\hline Hemorrhois hippocrepis & 77 & Tetouan (Morocco) & DQ451974/DQ451997 & E512.7 \\
\hline Hemorrhois hippocrepis & 78 & Marrackech (Morocco) & DQ451975/DQ452003 & E5113.3 \\
\hline Hemorrhois hippocrepis & 79 & Panta de Camarassa (Spain) & DQ451976/ & E1209.12 \\
\hline Hemorrhois hippocrepis & 80 & Tremp (Spain) & DQ451977/DQ451999 & E1209.13 \\
\hline Hemorrhois hippocrepis & 81 & Malgrat de Mar (Spain) & DQ451978/DQ452000 & E1209.9 \\
\hline Hemorrhois hippocrepis & 82 & San Juan de los Terreros, Almeria (Spain) & DQ451979/ & E512.11 \\
\hline Hemorrhois hippocrepis & 83 & Almuñecar (Spain) & DQ451980/ & E512.13 \\
\hline Hemorrhois hippocrepis & 84 & Sierra Nevada, Granada (Spain) & DQ451981/ & E512.18 \\
\hline Hemorrhois hippocrepis & 85 & Villanueva de Tapia, Granada (Spain) & DQ451982/ & E512.8 \\
\hline Hemorrhois hippocrepis & 86 & Hernán Pérez (Spain) & DQ451983/ & E512.9 \\
\hline Hemorrhois hippocrepis & 87 & Azrou/Ifrane (Morocco) & DQ451984/DQ452001 & E5113.1 \\
\hline Hemorrhois hippocrepis & 88 & Nebeur (Tunisia) & DQ451985/DQ452004 & E2509.10 \\
\hline Hemorrhois hippocrepis & 89 & $2 \mathrm{~km}$ E. of Hammam Bourguiba (Tunisia) & DQ451986/DQ452006 & E2509.8 \\
\hline Hemorrhois hippocrepis & 90 & Nebeur (Tunisia) & DQ451987/DQ452005 & E2509.9 \\
\hline
\end{tabular}

Specimen codes identify each individual sequenced (Figs. 2 and 4) and its locality (Fig. 1). NHMC followed by a number refers to voucher specimens deposited in the Natural History Museum of Crete.

\subsection{Phylogenetic analyses}

For the phylogenetic analyses four data sets were used: combined cytochrome $b$ and $12 \mathrm{~S}$ rRNA for 26 M. monspessulanus plus four outgroup taxa; cytochrome $b$ sequences alone for $39 \mathrm{M}$. m. monspessulanus plus one M. m. insignitus as an outgroup; combined cytochrome $b$ and $12 \mathrm{~S}$ rRNA sequences for $20 \mathrm{H}$. hippocrepis plus four outgroup taxa; cytochrome $b$ sequences alone for $37 \mathrm{H}$. hippocrepis plus one $H$. algirus as an outgroup. Sequences were aligned with ClustalX (Thompson et al., 1997) with default parameters (gap opening $=10$; gap extension $=0.2$ ). All the cytb sequences had the same length and therefore no gaps were postulated. These sequences were translated into amino acids using the vertebrate mitochondrial code and no stop codons were observed, suggesting that they were probably all functional. Although, some gaps were postulated to resolve length differences in the 12S rRNA gene fragment, all positions could be unambiguously aligned and were therefore included in the analyses.

Two methods of phylogenetic analysis were employed for all data sets and their results compared. These were maximum likelihood (ML) and maximum parsimony (MP). Modeltest v. 3.06 (Posada and Crandall, 1998) was used to select the most appropriate models of sequence evolution for the ML analyses, under the Akaike Information Criterion. For the two gene data sets, this was the general time reversible model (GTR), taking into account the number of invariant sites (I) and the shape parameter, alpha, of the gamma distribution $(\mathrm{G})$. For data sets comprising cytochrome $b$ alone, the Hishino-KasegawaYano (HKY) model was selected. The ML analyses were performed using PHYML (Guindon and Gascuel, 2003) with model parameters fitted to the data by likelihood maximization. MP analyses were performed in PAUP* v. $4.0 \mathrm{~b} 10$ (Swofford, 1998) and included heuristic searches involving tree bisection and reconnection (TBR) branch swapping with 100 random stepwise additions of taxa. All changes had the same weight and gaps were included as a fifth state. Reliability of the MP and ML trees was assessed by bootstrap analysis (Felsenstein, 1985), involving 1000 replications.

To evaluate divergence-time estimates, we first checked if our sequences were evolving in a clocklike manner. To do so, the $-\log$ likelihood values of the ML trees were compared with those of trees constructed from the same data under an assumption of regular change. As it is not presently possible to calibrate clocks internally for $M$. monspessulanus and $H$. hippocrepis, or for the more inclusive snake clades to which they belong, evolutionary rates estimated for other squamates are employed here. The taxa concerned are Tarentola geckos (Carranza et al., 2000, 2002), Gallotia lacertids (Maca-Meyer et al., 2003), and Chalcides skinks (Carranza and Arnold, unpublished data). The rates encountered are $1.35-2.4 \%$ of pairwise uncorrected genetic divergence per My for the combined cytochrome $b$ and 12S rRNA gene fragments used here, and 1.6-3.2\% of pairwise uncorrected genetic divergence per My for the cytochrome $b$ fragment on its own. All rates were estimated using the age of origin of El Hierro island in the Canary 
archipelago, assuming that it was colonized $1 \mathrm{Mya}$ (soon after its formation), by propagules from nearby La Gomera island from which currents run towards it (Guillou et al., 1996; Juan et al., 2000).

\subsection{Population genetics and demographic analyses}

Network approaches may be more effective than classical phylogenetic ones for representing intraspecific evolution (Posada and Crandall, 2001). The network of the mitochondrial Malpolon and Hemorrhois cytb haplotypes was inferred using statistical parsimony (Templeton et al., 1992), as implemented in the program TCSv1.13 (Clement et al., 2000). The method links haplotypes with the smallest number of differences as defined by a $95 \%$ confidence criterion.

Genetic differentiation between populations was calculated using the Snn statistic (Hudson, 2000) implemented in the program DnaSP version 4.10 .4 (Rozas et al., 2003). Haplotype and nucleotide diversity values were calculated with ARLEQUIN version 2.001 (Schneider et al., 2000). The same program was used to determine the historical demography of the populations using mismatch distributions with the models of Rogers and Harpending (1992) and Rogers (1995). Recent growth is expected to generate a unimodal distribution of pairwise differences between sequences (Rogers and Harpending, 1992). The distribution is compared with that expected under a model of population expansion (Rogers, 1995) calculating the estimator expansion time $(\pi)$ and the mutation parameter $(\varnothing)$ according to Schneider and Excoffier (1999). The fit of the mismatch distribution to the theoretical distribution under an expansion scenario was assessed by Montecarlo simulations of 1000 random samples with ARLEQUIN. The sum of squared deviations between observed and expected mismatch distributions was used as a test statistic and its $P$ value represents the probability of obtaining a simulated sum of squared deviations larger than or equal to the observed one. The history of effective population size was also assessed by means of other statistics including Tajima's D test (Tajima, 1989) and Fu's Fs test (Fu, 1997).

The formula $t=\pi /(2 u)$ was used to estimate the timing of population expansions, where $t$ is the approximate time of expansion in generations for Malpolon populations and $u$ is the mutation rate per sequence and generation. We set the mutation rate per lineage to a range between $0.008 / \mathrm{My}$ (equivalent to $1.6 \% / \mathrm{My}$ ) and $0.016 / \mathrm{My}$ (equivalent to $3.2 \% / \mathrm{My}$ ) because it is the range calculated for exactly the same regions of the mitochondrial cytochrome $b$ in other scleroglossan lizards from the Canary Islands, including Chalcides skinks, lacertid lizards, and Tarentola geckos (see above; Carranza and Amat, 2005; Carranza et al., 2004; Maca-Meyer et al., 2003).

\subsection{Criteria for species recognition}

The criteria for recognizing species used in this paper are those outlined by Good and Wake (1993), following Frost and Hillis (1990), and applied elsewhere, for example by García-París and Wake (2000) and Carranza and Amat (2005). In short, we consider as new species genetically cohesive units that are evolutionarily independent entities. Our main goal is to be able to recognize and to diagnose the taxa using morphological criteria but we also take biochemical evidence into consideration. When there is as much molecular differentiation between samples as between accepted species, morphology is investigated and, if it also shows differences, the units are also recognised as species.

\section{Results}

\subsection{Malpolon monspessulanus}

The combined data set for 27 individuals of M. monspessulanus consisted of $815 \mathrm{bp}$ of sequence ( $300 \mathrm{bp}$ of cytb and 515 of $12 \mathrm{~S}$ rRNA), of which $259 \mathrm{bp}$ were variable and $202 \mathrm{bp}$ parsimony-informative. The results of its analysis are shown in Fig. 2A. They group M. monspessulanus and M. moilensis as closest relatives among the colubrid species considered here, in agreement with morphology, although, this relationship needs to be tested further using a more complete psammophine data set. M. monspessulanus comprises two well-supported clades with an uncorrected genetic divergence of $8.4 \%$ for the combination of both genes $(12.8 \%$ for cytb only and $5.7 \%$ for $12 \mathrm{~S}$ rRNA only). One clade consists of $M$. m. insignitus from Tunisia, Egypt, and Cyprus and M. m. fuscus from Greece including both the Aegean islands and the mainland. The individuals from these four areas form a nested series, although, bootstrap support for this series is not strong. The second clade consists of M. m. monspessulanus from Algeria, Morocco, and the Iberian Peninsula. An individual from Essaouira in west Morocco is the sister taxon to a group containing the remainder, but again this has a rather low bootstrap support. The data set of cytochrome $b$ alone for 39 individuals of $M . m$. monspessulanus consisted of $300 \mathrm{bp}$ of which $45 \mathrm{bp}$ were variable and just $4 \mathrm{bp}$ parsimonyinformative. The results of phylogenetic analysis show very little structure within this subspecies (see Fig. 2B). The 11 North African and 28 Iberian animals do not separate into clear groups. The sample from Essaouira is again the sister taxon to all others with low support. Maximum uncorrected genetic divergence among all 39 specimens from 36 different localities sampled across more than $1,600,000 \mathrm{~km}^{2}$ of territory was $2.3 \%$ and a mere $0.6 \%$ if the most divergent single specimen from Essaouira is excluded.

The network of 10 cytochrome $b$ haplotypes from 11 North African and 28 Iberian samples is shown in Fig. 2C. All but one haplotype is represented by single individuals. The five haplotypes occurring exclusively in North Africa differ by up to $7 \mathrm{bp}$, and the four exclusive to Iberia by just $2 \mathrm{bp}$. One single haplotype is found on both sides of the Strait of Gibraltar, in six specimens from the Maghreb $(54 \%)$ and 24 from the Iberian Peninsula (85\%). Both 
A

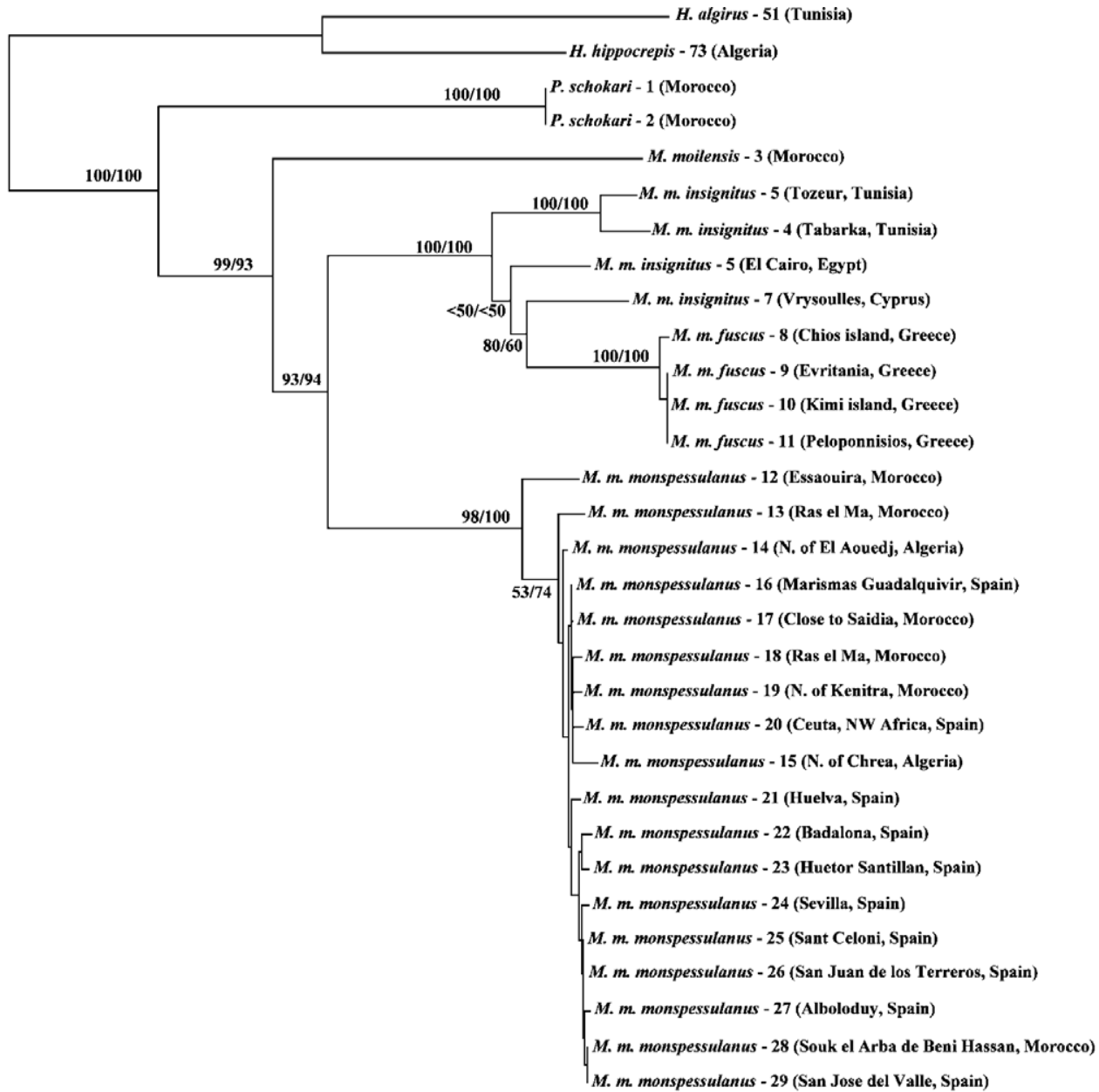

B

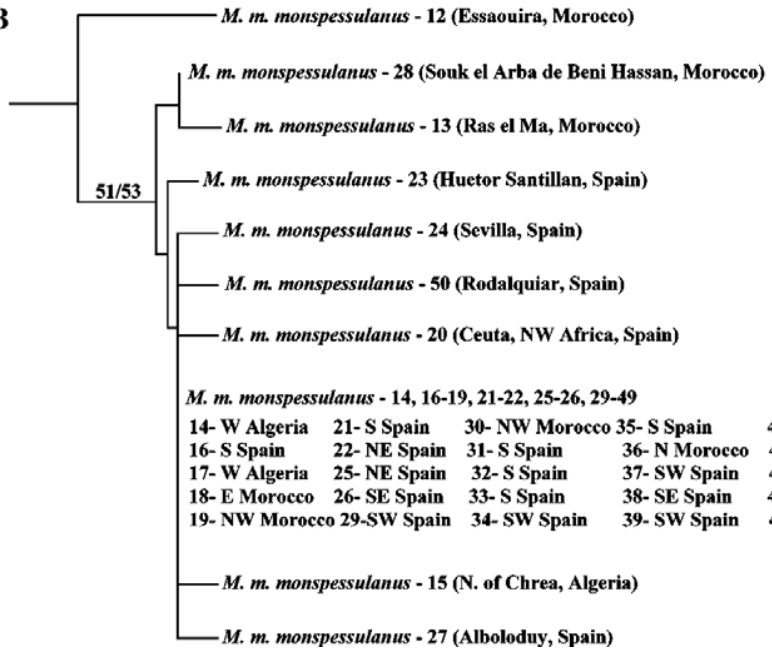

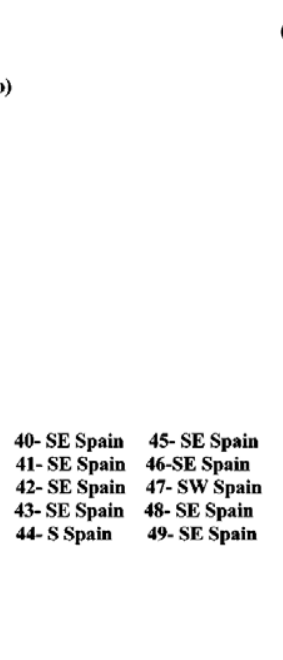

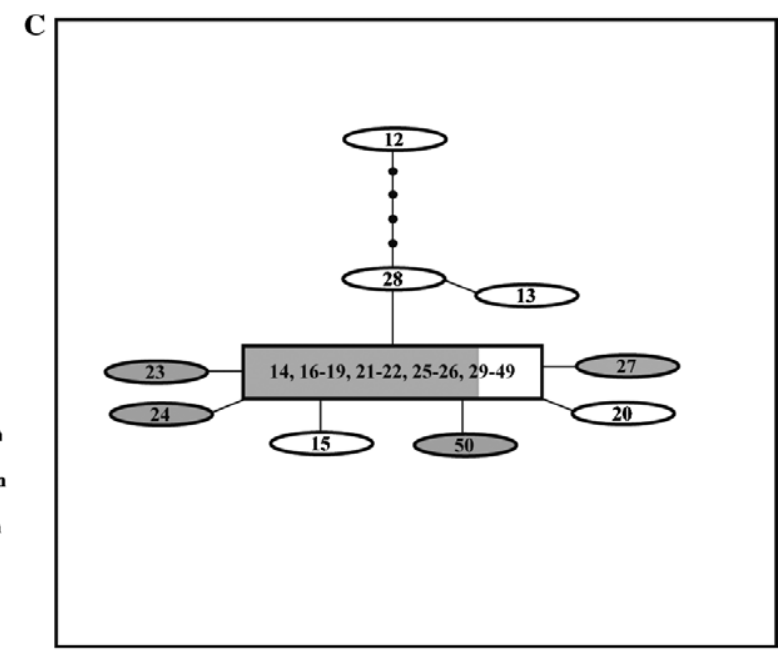

Fig. 2. (A) ML phylogenetic tree (GTR $+\mathrm{I}+\mathrm{G})$ for Malpolon monspessulanus inferred using PHYML with a combined data set including 300 bp of cytochrome $b$ and $515 \mathrm{bp}$ of $12 \mathrm{~S}$ rRNA mitochondrial sequences. (B) ML phylogenetic tree (HKY) of M. monspessulanus inferred using PHYML including $300 \mathrm{bp}$ of cytochrome $b$ only. In both phylogenetic trees (A and B) numbers by the nodes indicate bootstrap support values above $50 \%$ for ML and MP analyses, respectively. Numbers after species names refer to specimen codes shown in Table 1 and Fig. 1. Several consecutive numbers after a single species name indicate that all sequences are identical. (C) Minimum spanning network of all identified haplotypes of M. monspessulanus. Numbers refer to specimen codes in Table 1 and Fig. 1. Shaded ovals indicate haplotypes confined to Iberia, unfilled ovals ones confined to the Maghreb. The rectangle represents the commonest haplotype, which occurs in both Iberia and the Maghreb; the amount of shading indicates the proportion of Iberian cases, the un-shaded area those in the Maghreb. Every dot indicates a single mutational step. 
populations showed relatively high values of haplotype diversity and low values of nucleotide diversity (see Table 2). The results of the Snn test (Hudson, 2000) indicate that the Iberian and Maghreb populations of M. m. monspessulanus are differentiated (Snn value of $0.66397 ; P<0.001$ ). This being so, demographic analyses were performed independently for the two populations. For both Iberia and the Maghreb, the mismatch distributions were not significantly different from the sudden expansion model of Rogers and Harpending (1992) (Table 3 and Fig. 3). But other tests of changes in population size, Tajima's D and Fu's Fs, were significant for Iberia alone and not for the Maghreb. We have consequently estimated an approximate time of expansion for M. m. monspessulanus in Iberia. This was about 20,911-55,763 generations ago, depending on the estimates of mutation rate (1.6 and $3.2 \%$ per My, see above). Investigations by Hueso (1997) indicate that males of M. m. monspessulanus attain sexual maturity in about 3 years (at a length of $550 \mathrm{~mm}$ from snout to vent) and females in about 4 years (at a length of $635 \mathrm{~mm}$ from snout to vent), so the expansion in Iberia may have occurred approximately 83,000168,000 years ago.

\subsection{Hemorrhois hippocrepis}

The combined data set for 20 individuals of $H$. hippocrepis consisted of $695 \mathrm{bp}$ of sequence (300 bp of cytb and 395 of $12 \mathrm{~S}$ ), of which $202 \mathrm{bp}$ were variable and $145 \mathrm{bp}$ parsimony-informative. The results of its analysis are shown in Fig. 4A and corroborate observations from morphology that $H$. hippocrepis is most closely related to $H$. algirus among the colubrid species considered here. All individuals form a single clade with little internal phylogenetic structure, except that three animals from Tunisia group together with a relatively high bootstrap value. Excluding these, the 12 specimens from the Maghreb and the five from the Iberian Peninsula are phylogenetically intermixed. The data set for cytochrome $b$ alone for 37 individuals of $H$. hippocrepis consisted of $300 \mathrm{bp}$ of which 50 were variable and 44 parsimony-informative. The results of its analysis (Fig. 4B) again show very little structure, with the three Tunisian individuals being outside a well-supported clade containing the rest. Maximum uncorrected genetic divergence among the 37 specimens
Table 3

Neutrality tests for $M . m$. monspessulanus and H. hippocrepis

\begin{tabular}{lll}
\hline & Iberia & North Africa \\
\hline $\begin{array}{ll}\text { M. } m . \text { monspessulanus } \\
\text { Tau }\end{array}$ & 0.803 & \\
Theta0 & 0.000 & 1.172 \\
Theta1 & 0.388 & 0.000 \\
Goodness of fit test & & 313.75 \\
$\quad$ SSD & 0.0037 & \\
$P$ & 0.4390 & 0.0242 \\
Tajima's D test & -1.88915 & 0.2940 \\
$P$ & $<0.05$ & -1.61637 \\
Fu's Fs test & -4.27082 & $\mathrm{NS}$ \\
$P$ & $<0.001$ & -1.70684 \\
H. hippocrepis & & $\mathrm{NS}$ \\
Tau & 3.559 & \\
Theta0 & 0.002 & 6.529 \\
Theta1 & 2.930 & 0.002 \\
Goodness of fit test & & 3.480 \\
$\quad$ SSD & 0.0988 & \\
$P$ & 0.0440 & 0.0530 \\
Tajima's D test & 2.09605 & 0.3300 \\
$P$ & $\mathrm{NS}$ & -1.22437 \\
Fu's Fs test & 2.14426 & $\mathrm{NS}$ \\
$P$ & $\mathrm{NS}$ & -1.27712 \\
\hline
\end{tabular}

NS, not significant.

from 34 different localities sampled across more than $700,000 \mathrm{~km}^{2}$ of territory $(80 \%$ of its total distribution area) was $1.6 \%$.

The network analysis of cytb (Fig. 4C) for 20 North African and 17 Iberian samples reveals 10 haplotypes, four of which are represented by single individuals, two by two, two by three, and one by six. The seven haplotypes occurring exclusively in North Africa differ by up to $12 \mathrm{bp}$, while the two haplotypes exclusive to Iberia vary by just $2 \mathrm{bp}$. One single haplotype is found on both sides of the Strait of Gibraltar, in eight specimens from the Maghreb (40\%) and nine from the Iberian Peninsula (56\%). Both populations showed relatively high value of haplotype diversity and low values of nucleotide diversity (see Table 2). The results of the Snn test (Hudson, 2000) indicate that the Iberian and Maghreb populations of $H$. hippocrepis are differentiated ( $S n n$ value of $0.68680 ; P<0.001$ ). Because of this, demographic analyses were performed independently for the two populations. The mismatch distributions were sig-

Table 2

Haplotypes and diversity measures for populations of Hemorrhois hippocrepis and Malpolon m. monspessulanus

\begin{tabular}{|c|c|c|c|c|}
\hline & H. hippocrepis & & M. m. monspessulanus & \\
\hline Geographical areas & Maghreb & Iberian Penin. & Maghreb & Iberian Penin. \\
\hline Number of samples & 20 & 17 & 11 & 28 \\
\hline Haplotypes shared between both areas & 1 & 1 & 1 & 1 \\
\hline Individuals with shared haplotype & $8(40 \%)$ & $9(53 \%)$ & $6(54 \%)$ & $24(85 \%)$ \\
\hline Haplotypes exclusive to region & 7 & 2 & 5 & 4 \\
\hline Maximum number of differences between haplotypes & 12 & 3 & 7 & 2 \\
\hline Haplotype diversity & $0.815 \pm 0.070$ & $0.617 \pm 0.076$ & $0.727 \pm 0.144$ & $0.269 \pm 0.109$ \\
\hline Nucleotide diversity & $0.00875 \pm 0.0054$ & $0.00514 \pm 0.0036$ & $0.00630 \pm 0.0043$ & $0.00095 \pm 0.0011$ \\
\hline
\end{tabular}




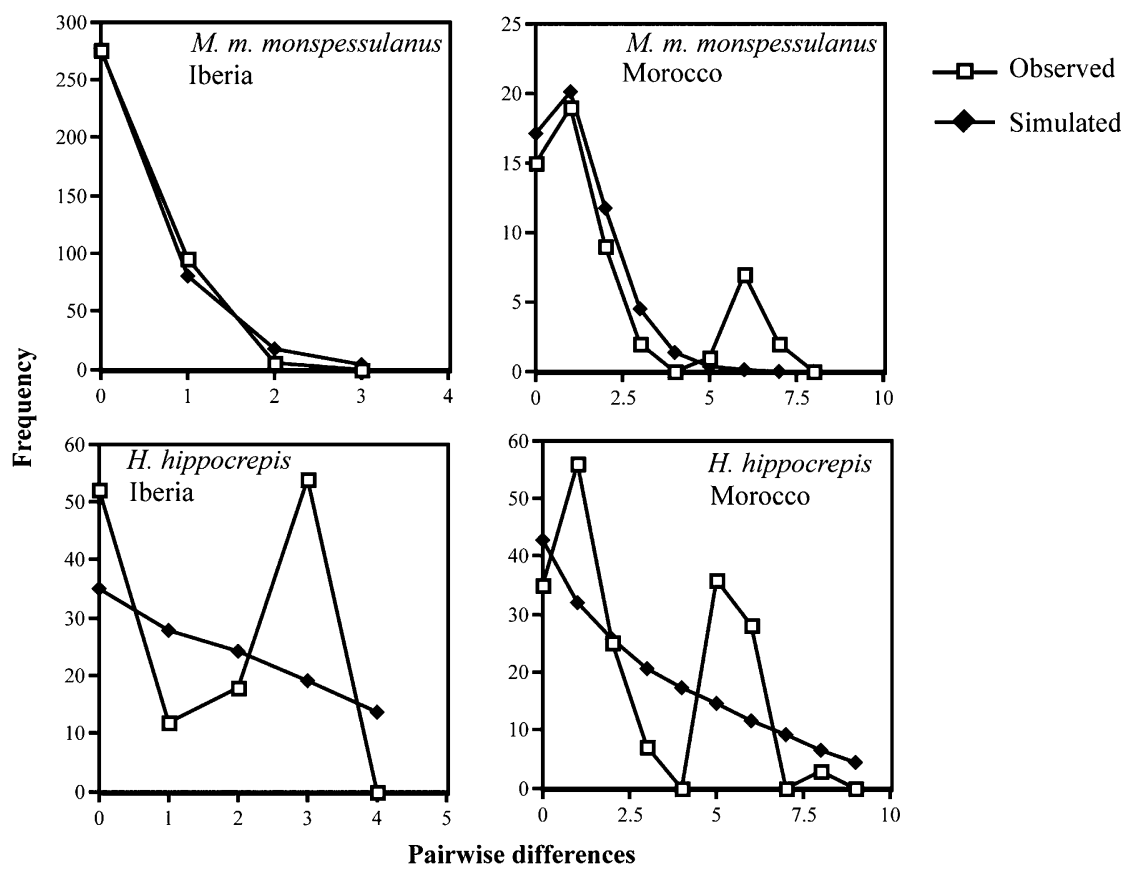

Fig. 3. Mismatch distribution of M. m. monspessulanus and Hemorrhois hippocrepis considering the cytb sequences. Observed relative frequencies between pairs of individuals in open squares and the distribution fitted to the data under a model of population expansion in filled squares.

nificantly different from the sudden expansion model of Rogers and Harpending (1992) for both Iberia and Maghreb (Table 3 and Fig. 3). Similarly, other tests of change in population size, Tajima's D and Fu's F, did not indicate sudden expansion in either region.

\subsection{Molecular clock}

When the $-\log$ likelihood value of the ML trees for the combined gene fragments (Figs. 2A and 3A) were compared with the $-\log$ likelihood of the same trees constructed under molecular clock assumptions, there were no significant differences. Malpolon monspessulanus: $-\log$ likelihood 3040.722, under molecular clock assumption 3056.573; likelihood ratio test statistic $(-2 \log \Delta)=31.702$, which approximates a $X_{29}^{2}$ distribution under the null hypothesis; $P>0.05$. Hemorrhois hippocrepis: $-\log$ likelihood 2160.691, under molecular clock assumption 2172.630; likelihood ratio test statistic $(-2 \log \Delta)=23.878$, which approximates a $X_{23}^{2}$ distribution under the null hypothesis; $P>0.05$. So sequences were evolving in a clocklike way and phylogenies can be used to estimate dates.

\section{Discussion}

\subsection{Biogeography of Malpolon monspessulanus}

There are several indications that the lineage of $M$. monspessulanus has had a long history in Africa: First, it belongs to an essentially African assemblage, the Psammophinae (Kelly et al., 2003), of which all genera occur within the continent and only Psammophis and Malpolon extend outside it (Psammophis reaches southern Asia including India while Malpolon occurs in Southwest Asia and southern Europe). Second, parsimony suggests that the sister species of M. monspessulanus, M. moilenis, is also likely to be African in origin, even though it extends into Arabia. Molecular clock considerations (see Section 2; rate of 1.35$2.4 \%$ of pairwise uncorrected genetic divergence per My for the combined data set) indicate that the two separated about 4.6-8 Mya. Third, the deepest dichotomy within M. monspessulanus, which is estimated to have occurred 3.5-6 Mya, is likely to have arisen in the Maghreb. This is the only area where the two resultant clades are in close proximity; they also each have basal branches there. Fourth, although, it occurs in Europe, M. monspessulanus

Fig. 4 (A) ML phylogenetic tree (GTR $+\mathrm{I}+\mathrm{G})$ for Hemorrhois hippocrepis inferred using PHYML with a combined data set including 300 bp of cytochrome $b$ and $395 \mathrm{bp}$ of $12 \mathrm{~S}$ rRNA mitochondrial sequences. (B) ML phylogenetic tree (HKY) of H. hippocrepis inferred using PHYML with a data set including $300 \mathrm{bp}$ of cytochrome $b$ only. In both trees (A and B) numbers by nodes indicate bootstrap support values above $50 \%$ for ML and MP analyses, respectively. Numbers after species names refer to specimen codes shown in Table 1 and Fig. 1. Several consecutive numbers after a species name indicate that all the sequences concerned are identical. (C) Minimum spanning network of all identified haplotypes of $H$. hippocrepis. Numbers refer to specimen codes in Table 1 and Fig. 1. Shaded ovals indicate haplotypes confined to Iberia, unfilled ones indicate haplotypes confined to the Maghreb. The rectangle represents the commonest haplotype, which occurs in both Iberia and the Maghreb; the amount of shading indicates the proportion of Iberian cases, the un-shaded area those in the Maghreb. Every dot indicates a single mutational step. 
A

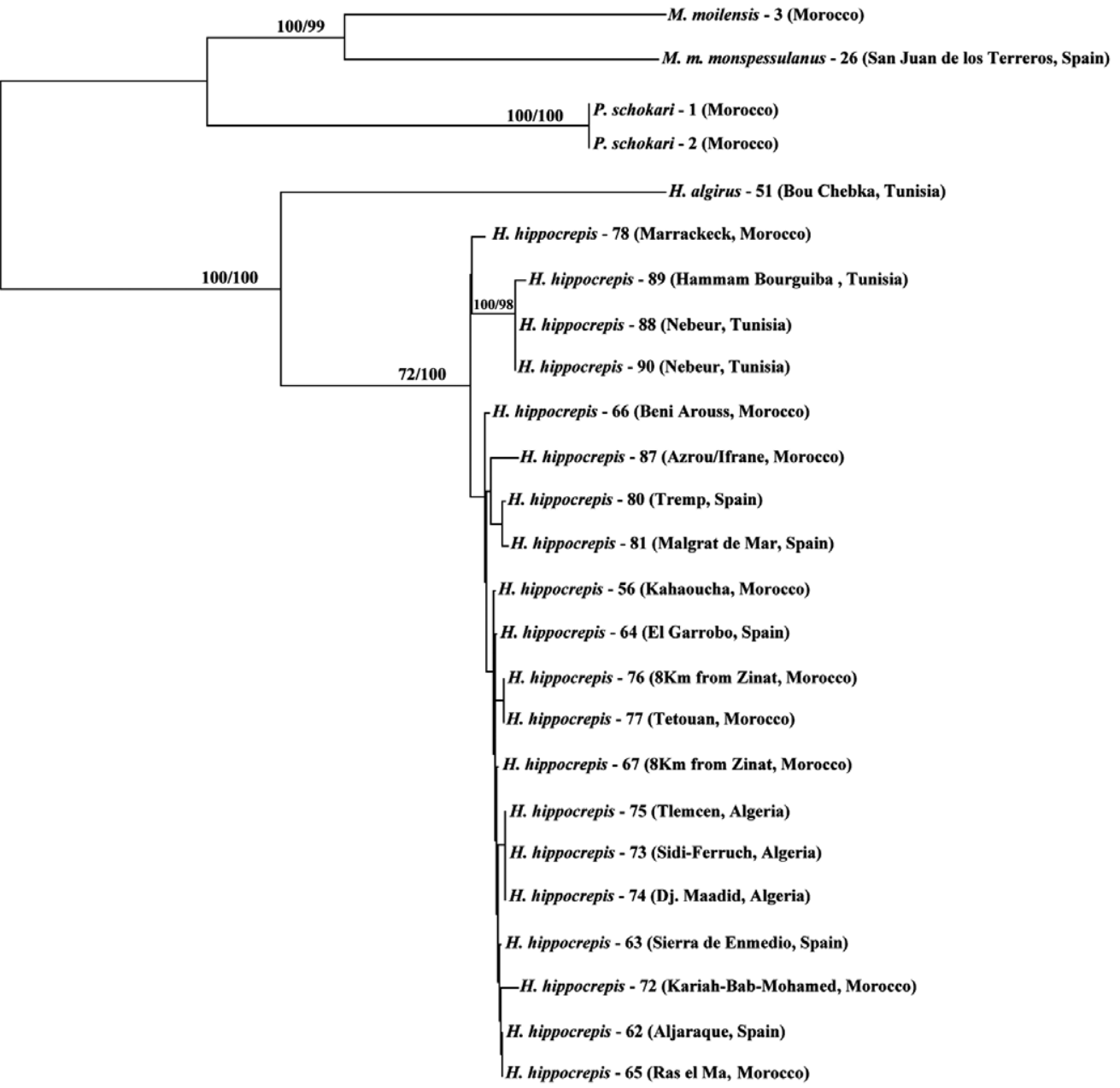

B

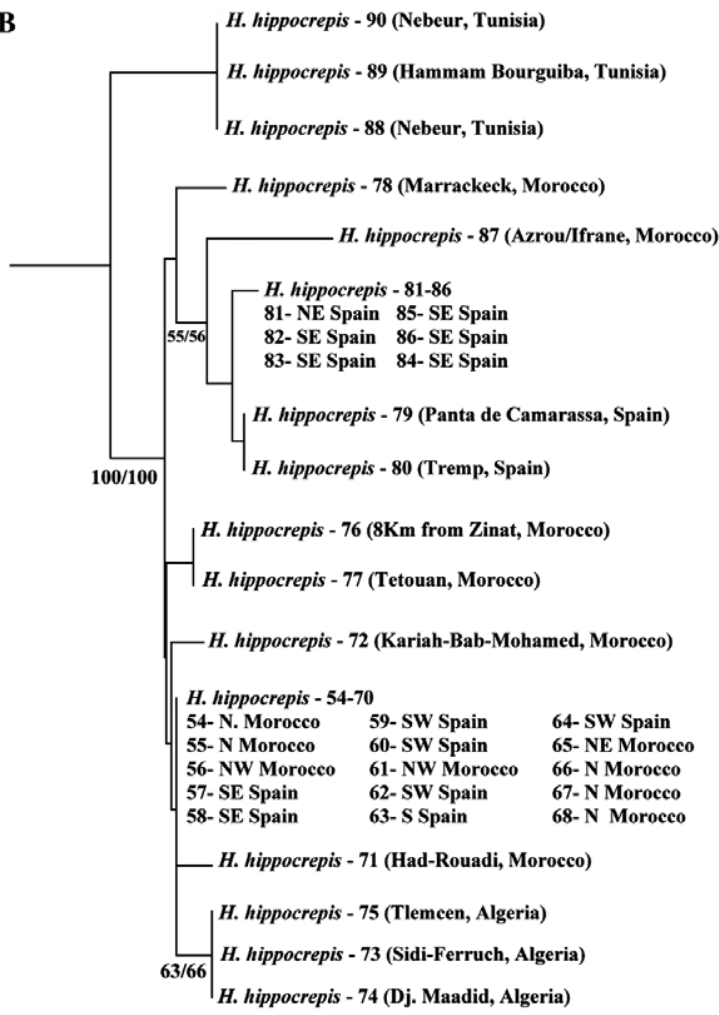

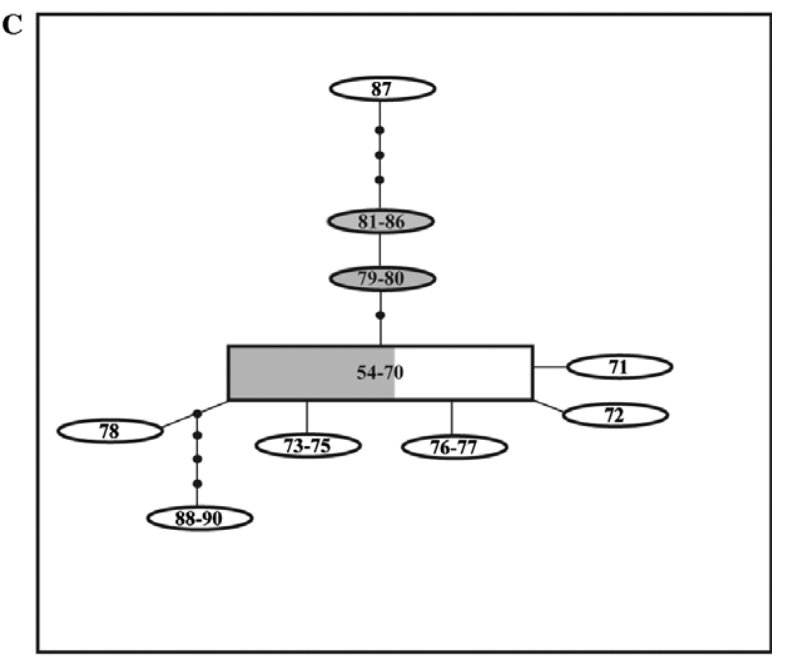

69- SW Spain 70- SE Spain 
has a spermatogenic cycle that appears adapted to areas with particularly long and hot springs and summers, like the Maghreb. Spermatogenesis occurs immediately after hibernation (Cheylan et al., 1981), and copulation, egg-laying, embryogenesis and hatching all occur within the same calendar year. This life history contrasts with that of species of Eurasian origin that now occur alongside M. monspessulanus in the Iberian Peninsula, such as Coronella girondica, Rhinechis scalaris, Natrix natrix, and N. maura. In these, spermatogenesis occurs in the warmest period of the year (summer) but because of time constraints, the process from mating to hatching does not occur until the end of hibernation, in the following calendar year (Feriche, 1998; Pleguezuelos and Feriche, 1999; Pleguezuelos and Feriche, in press).

The most parsimonious interpretation of the phylogeny of M. monspessulanus is that it dispersed in two directions, east and west, out of the Maghreb, with M. m. monspessulanus reaching Southwest Europe, and the clade consisting of M. m. insignitus and M. m. fuscus progressing eastwards into Egypt, through Israel, Lebanon, Jordan and into Syria, Iraq, and Iran, and around the northeast Mediterranean through western Turkey to the Balkan Peninsula. A similar double dispersal from the Maghreb has also occurred in Chalcides skinks (Carranza and Arnold, unpublished data).

A further indication that dispersal was from the Maghreb into Southwest Europe is that nucleotide diversity is approximately 10 times lower in the second region (see Table 2), even though the sample of individuals and localities is much larger. Southwest Europe lacks the diversity produced by the presence of the Essaouira sample in the Maghreb and has just two very similar exclusive haplotypes compared with seven much more varied ones in the latter area. The limited nucleotide diversity that has apparently evolved in Southwest Europe would fit with a recent demographic expansion in the late-Pleistocene (see Table 3 and Fig. 3). It is difficult to put a date on spread into Southwest Europe on the basis of the molecular phylogeny, as the gene fragments used here change relatively slowly, but demographic analyses suggest the population expansion that probably followed invasion from the Maghreb might have happened 83,645-167,290 years ago. If recent origin of Southwest European M. m. monspessulanus is accepted, the Pliocene and at least some of the Pleistocene fossil record of Malpolon in Southwest Europe must represent an earlier invasion from the source area in Africa. This may have been across the land bridge that existed in the Messinian period. The descendants of this invasion became extinct subsequently, perhaps during one of the cold phases that accompanied Pleistocene glaciations. The distinctive reproductive cycle of $M$. monspessulanus, in which all activities occur within one season, may have made them vulnerable to extinction in this geological interlude, when summers were short and cool. Male M. m. monspessulanus need a mean July temperature of $22^{\circ} \mathrm{C}$ or higher for spermatogenesis to occur (Saint-Girons, 1982). Other examples of snake groups adapted to much warmer climatic condi- tions that are no longer present in Iberia but known from its fossil record include a cat snake (Telescopus), a sand boa (Eryx, Boidae) known from the Pliocene of Spain (Szyndlar and Schleich, 1994) and another boa, Bavarioboa and a cobra (Naja, Elapidae) known from the middle/upper Miocene (Szyndlar, 2000; Szyndlar and Rage, 1990). Two vertebrae similar to those of Telescopus have been reported from Gibraltar shortly before the last glacial 25,00095,000 years ago (Gleed-Owen, 2001).

In comparison to its western clade, the eastern clade of M. monspessulanus shows much more genetic diversity. This and the nested nature of its internal phylogeny indicate that its spread around the eastern Mediterranean Sea, to Southwest Asia and ultimately Southeast Europe, began earlier and probably occurred over a longer period. Moreover, the area covered by the eastern clade is much bigger and physiogeographically more complex than that covered by the western clade.

\subsection{Taxonomy of Malpolon monspessulanus}

There are clear morphological differences between $M . m$. monspessulanus and the more eastern $M . m$. insignitus and $M$. m. fuscus. These two units possess different ranges of colour patterns, and distinctive osteological features have also been reported (Szyndlar, 1988). The basioccipital bone of M. m. monspessulanus has a single, median, posteriorly directed process that forms a strong spur, while this is replaced by two separate processes or indistinct callosities in eastern populations. These morphological differences correlate with a marked genetic divergence between $M$. m. monspessulanus and the eastern subspecies of $8.4 \%$ for the combined mitochondrial gene fragments investigated here, each of which shows substantial independent divergence $(12.8 \%$ for cytb and $5.7 \%$ for $12 \mathrm{~S}$ rRNA). This is greater than in many recognised reptile species (Harris, 2002). In view of the marked divergence in different aspects of morphology and different mitochondrial gene fragments, it is recommended that the two units should be treated as separate species: M. monspessulanus (sensu stricto), and Malpolon insignitus (Geoffroy Saint-Hilaire, 1827) stat. nov. including the as yet poorly defined subspecies Malpolon insignitus fuscus (Fleichsmann, 1831) comb. nov.

\subsection{Hemorrhois hippocrepis}

Like M. monspessulanus, $H$. hippocrepis has a sister species, $H$. algirus, in rather drier areas of the Maghreb. The molecular clock used here suggests that the two separated about 4-7 Mya. Presence in the Maghreb of both H. hippocrepis and its sister species makes it most parsimonious to assume that this snake originated in the region and later dispersed to the Iberian Peninsula. The very low differentiation between populations on each side of the strait suggests that this was quite recent. The neutrality tests indicate no recent demographic expansion in either Maghreb or Iberian populations of $H$. hippocrepis (see Table 
3 and Fig. 3), but this will have to be confirmed by including more samples. As with M. m. monspessulanus the commonest haplotype in the Maghreb also occurs in the Iberian Peninsula. Although, reptiles have quite a good fossil record from the Pliocene and Pleistocene of Southwest Europe, material assigned to $H$. hippocrepis is sparse and relatively recent (3000-95,000 years-Bailón, 1986; Gleed-Owen, 2001; López-Martínez and Sanchiz, 1981). Another line of evidence for a southern origin of $H$. hippocrepis is provided by its ecology. Pleguezuelos and Fahd (2004), studying populations of H. hippocrepis on each side of the Strait of Gibraltar, found that the ecological diversity of the diet was higher in Morocco than in Iberia $\left(H^{\prime}=2.54\right.$ versus $\left.H^{\prime}=1.91\right)$, despite the Iberian sample size being 1.5 times higher than the Moroccan one. Since it has been reported that snakes show higher trophic diversity on their area of origin (Pleguezuelos and Fahd, 2004), this would support a North African origin of H. hippocrepis. The reproductive cycle of $H$. hippocrepis is like that of $M$. monspessulanus and, as in that species, provides additional circumstantial evidence for its southern origin (see Pleguezuelos, 1998b; Pleguezuelos and Fahd, 2004; Pleguezuelos and Feriche, 1999).

\subsection{Possible means of colonizing Southwest Europe}

As already noted, the lack of strong differentiation in mtDNA sequence between Maghreb and Southwest European $M . m$. monspessulanus and $H$. hippocrepis suggests that movement between the two areas was relatively recent. But limited divergence among the haplotypes concerned prevents any precise estimate of dates for invasion. However, the estimated date of expansion of M. monspessulanus in Iberia indicates that it has been present there for at least $82000-168000$ years. If this minimum time of occupation is accepted, the snake is likely to have arrived by natural means rather than being a recent human introduction. Direct transmarine migration between the Maghreb and Iberia seems unlikely, given that it had not happened in the $4 \mathrm{My}$ or more after the Strait of Gibraltar opened at the end of the Messinian, even though the H. hippocrepis and possibly $M$. m. monspessulanus lineages were in existence throughout this period. The same applies to other reptiles and amphibians that also seem to have dispersed across the Strait of Gibraltar only in very recent times despite having long-standing populations on one of the two sides, for instance Macroprotodon brevis ibericus, Hyla meridionalis, E. orbicularis, M. caspica, Podarcis vaucheri, Pleurodeles waltl, T. graeca, and C. chamaeleon (Álvarez et al., 2000; Batista et al., 2004; Busack, 1986; Busack et al., 2005; Carranza and Arnold, 2004; Fritz et al., 2005; Harris et al., 2002; Lenk et al., 1999; Paulo et al., 2002).

An alternative possibility is suggested by the bathymetry of the Strait of Gibraltar and climatic events during the Pleistocene period. The floor of the strait has a very complex topography including several ridges, so that depths vary greatly (Brandt et al., 1996; Cadiz, 1998). The shal- lowest sections are on an almost straight line from Cape Malabata in Morocco to Punta Paloma in Spain. On this eminence, known as the Camarinal Sill, the present maximum water depth is $290 \mathrm{~m}$, but in many places it is much shallower, ranging between 40 and $150 \mathrm{~m}$ (Brandt et al., 1996; Cadiz, 1998). Given that sea levels in the area of the Strait of Gibraltar dropped by approximately $130 \mathrm{~m}$ during Pleistocene glaciations (C Finlayson, pers. commun.; see also Andersen and Borns, 1997), some of the higher parts of this area of the Camarinal Sill are likely to have been exposed at that time as temporary small islands. This may have enabled some terrestrial vertebrates, like the snakes investigated here, to 'hop' across the Strait of Gibraltar quite recently.

\subsection{Comparison of the South Iberian snake fauna with climatically similar parts of Europe}

The taxa that are likely to have arrived recently in Southwest Europe from the Maghreb constitute a significant proportion of the herpetofauna of the southern Iberian Peninsula. This is especially true for the snakes, with three of the nine south Iberian species probably originating in this way (M. monspessulanus, $H$. hippocrepis, and Macroprotodon brevis ibericus - Carranza et al., 2004). The other snakes present in the region are all European in origin, namely Natrix natrix, N. maura, Coronella austriaca, C. girondica, $R$. scalaris, and Vipera latasti. The quite small total snake fauna is similar in number to the 10 species in southern France and 10 in southern Italy, all of which are probably European in origin, except M. monspessulanus in France. In contrast, the southern Balkan Peninsula has 16 species of snakes, a high proportion of which are shared with Turkey and the Levant. These latter regions may represent the source of the Balkan populations of many species, as is shown here in $M$. monspessulanus. Little is known about dates of arrival in the Balkans, but presence may sometimes be long-standing and pre-date the last glaciations.

\section{Acknowledgments}

We are indebted to J. Roca for technical support. The authors of the "Atlas Herpetológico de Andalucia," namely J.P. Gonzalez de la Vega, D. Donaire, J.M. Barnestein, and L. García, provided many of the samples of Malpolon $m$. monspessulanus and $H$. hippocrepis from Southern Spain. M. Vila donated additional Spanish H. hippocrepis samples from Tremp and Camarassa, and P. Limberakis, from the Natural History Museum of Crete, all samples of M. m. fuscus from Greece. Most of the Maghreb samples used in this study came from D. Donaire who also provided advice. J. Rozas, S. Ramos-Onsins, and L. Bidegaray provided advice on the population and demographic analyses. We are also grateful for the comments of Allan Larson, associate editor of MPE, and two anonymous referees, which have substantially improved the manuscript. The project was supported by grants from 
the Natural Environment Research Council (NERC) NER/B/S/2000/00714 and NER/A/S/2001/00511 to E.N. Arnold, by project CGL2005-06876/BOS of the Ministerio de Educación y Ciencia, Spain, and by Grant 2005SGR00045 (Grup de Recerca Emergent) from the Generalitat de Catalunya. S. Carranza is supported by a Ramón y Cajal contract from the Ministerio de Educación y Ciencia, Spain.

\section{References}

Álvarez, Y., Mateo, J.A., Andreu, A.C., Díaz-Paniagua, C., Díez, A., Bautista, J.M., 2000. Mitochondrial DNA haplotyping of Testudo graeca on both continental sides of the Straits of Gibraltar. J. Hered. $91,39-41$.

Andersen, B.G., Borns Jr., H.W., 1997. The Ice Age world. Scandinavian University Press, Oslo.

Arntzen, J.W., Garcia-Paris, M., 1995. Morphological and allozyme studies of midwife toads (genus Alytes), including the description of two new taxa from Spain. Contr. Zool. 65, 5-34.

Bailón, S., 1986. Los anfibios y los reptiles del yacimiento de Cueva-Horá (Darro, Granada). Antrop. Paleon. Hum. 4, 131-155.

Bailón, S., 1991. Le genre Malpolon (Serpentes, Colubridae) dans les gisements français. Bull. Soc. Herp. Fr. 58, 1-10.

Bailón, S., 2000. Amphibiens et reptiles du Pliocene terminal d'Ahl Oughlam (Casablanca, Maroc). Geodiversitas 22, 539-558.

Balin, H., 2005. Contribution de la Paleoherpetofaune (Amphibia, Squamata), à la connaissance de l'évolution du climat et du Paysage du Pliocène supérieur au Pléistocène moyen d'Espagne. Ph.D. thesis. Museum National d'Histoire Naturelle de Paris, Paris, France, pp. 402.

Barroso, C., Bailón, S. 2003. Los anfibios y los reptiles del Pleistoceno superior de la cueva del Boquete de Zafarraya (Málaga, España). In: Barroso, C. (Ed.), Monografías de Arqueología. Consejería de Cultura, Junta de Andalucía, Sevilla, pp. 267-278.

Batista, V., Harris, D.J., Carretero, M.A., 2004. Genetic variation in Pleurodeles walt Michaelles, 1830 (Amphibia: Salamandridae) across the Strait of Gibraltar derived from mitochondrial DNA sequences. Herpetozoa 16, 166-168.

Brandt, P., Alpers, W., Backhaus, J.O., 1996. Study of the generation and propagation of internal waves in the Strait of Gibraltar using a numerical model and synthetic aperture radar images of the European ERS 1 satellite. J. Geophys. Res. 101, 14237-14252.

Busack, S.D., 1986. Biogeographic analysis of the herpetofauna separated by the formation of the Strait of Gibraltar. Natl. Geogr. Res. 2, $17-36$.

Busack, S.D., Lawson, R., Wendy, M.A., 2005. Mitochondrial DNA, allozymes, morphology and historical biogeography in the Podarcis vaucheri (Lacertidae) species complex. Amphibia-Reptilia 26, 239-256.

Carranza, S., Amat, F., 2005. Taxonomy, biogeography and evolution of Euproctus (Amphibia: Salamandridae), with the resurrection of the genus Calotriton and the description of a new endemic species from the Iberian Peninsula. Zool. J. Linn. Soc. 145, 555-582.

Carranza, S., Arnold, E.N., 2004. History of west Mediterranean newts, Pleurodeles (Amphibia: Salamandridae), inferred from old and recent DNA sequences. Syst. Biodiv. 1, 327-337.

Carranza, S., Arnold, E.N., Mateo, J.A., Geniez, P., 2002. Relationships and evolution of the North African geckos, Geckonia and Tarentola (Reptilia: Gekkonidae), based on mitochondrial and nuclear DNA sequences. Mol. Phylogenet. Evol. 23, 244-256.

Carranza, S., Arnold, E.N., Mateo, J.A., López-Jurado, L.F., 2000. Longdistance colonization and radiation in gekkonid lizards, Tarentola (Reptilia: Gekkonidae), revealed by mitochondrial DNA sequences. Proc. R. Soc. Lond. B. 267, 637-649.

Carranza, S., Arnold, E.N., Thomas, R.H., Mateo, J.A., López-Jurado, L.F., 1999. Status of the extinct giant lacertid lizard Gallotia simonyi simonyi (Reptilia: Lacertidae) assessed using mtDNA sequences from museum specimens. Herpetol. J. 9, 83-86.

Carranza, S., Arnold, E.N., Wade, E., Fahd, S., 2004. Phylogeography of the false smooth snakes, Macroprotodon (Serpentes, Colubridae): mitochondrial DNA sequences show European populations arrived recently from Northwest Africa. Mol. Phylogenet. Evol. 33, 523-532.

Carranza, S., Harris, J.D., Arnold, E.N., Batista, V., Lopez, J.P., in press. Phylogeography of the Algerian Sand Racer, Psammodromus algirus, across the Strait of Gibraltar. J. Biogreogr.

Carranza, S., Wade, E., 2004. Taxonomic revision of Algero-Tunisian Pleurodeles (Caudata: Salamandridae) using molecular and morphological data. Revalidation of the taxon Pleurodeles nebulosus (Guichenot, 1850). Zootaxa 488, 1-24.

Cheylan, M., Bons, J., Saint-Girons, H., 1981. Evidence of a vernal cycle and prenuptial spermatogenetic cycle in a Mediterranean snake Malpolon monspessulanus (Reptilia: Colubridae). C. R. Acad. Sci. París 292, 1207-1209.

Clement, M., Posada, D., Crandall, K.A., 2000. TCS: a computer program to estimate gene genealogies. Mol. Ecol. 9, 1657-1659.

De Haan, C.C., 1999. Malpolon monspessulanus (Hermann, 1804)_Europäische Eidechsennatter. In: Böhme, W. (Ed.), Handbuch der Reptilien und Amphibien Europas. 3/IIA (Schlangen II). AulaVerlag, pp. 661-756.

Duggen, S., Hoernle, K., van den Bogaard, P., Rupke, L., Morgan, J.P., 2003. Deep roots of the Messinian salinity crisis. Nature, 602-605.

Escoriza, D., Comas, M.M., Donaire, D., Carranza, S., in press. Rediscovery of Salamandra algira Bedriaga, 1833 from the Beni Snassen massif (Morocco) and phylogenetic relationships of North African Salamandra. Amphibia-Reptilia.

Felsenstein, J., 1985. Confidence-limits on phylogenies-an approach using the bootstrap. Evolution 39, 783-791.

Feriche, M., 1998. Ecología de la reproducción en colúbridos del sureste de la Península Ibérica. Ph.D. Thesis: University of Granada, Spain.

Fritz, U., Fritzsch, G., Lehr, E., Ducotterd, J.M., Müller, A., 2005. The Atlas Mountains, not the Strait of Gibraltar, as a biogeographic barrier for Mauremys leprosa (Reptilia: Testudines). Salamandra 41, 97-106.

Fromhage, L., Vences, M., Veith, M., 2004. Testing alternative vicariance scenarios in Western Mediterranean discoglossid frogs. Mol. Phylogenet. Evol. 31, 308-322.

Frost, D.R., Hillis, D., 1990. Species in concept and practice: herpetological applications. Herpetologica 46, 87-104.

Fu, Y.X., 1997. Statistical tests of neutrality of mutations against population growth, hitchhiking and background selection. Genetics 147, 915-925.

García-París, M., Buchholz, D.R., Parra-Olea, G., 2003. Phylogenetic relationships of Pelobatoidea re-examined using mtDNA. Mol. Phylogenet. Evol. 28, 12-23.

García-París, M., Jockusch, E.L., 1999. A mitochondrial DNA perspective on the evolution of Iberian Discoglossus (Amphibia: Anura). J. Zool. 248, 209-218.

García-París, M., Wake, D.B., 2000. Molecular phylogenetic analysis of relationships of the tropical salamander genera Oedipina and Nototriton, with descriptions of a new genus and three new species. Copeia 2000, 42-70.

Gleed-Owen, C.P., 2001. A preliminary report on the late Pleistocene amphibians and reptiles from Gorham's cave and Vanguard cave, Gibraltar. Herpetol. J. 11, 167-170.

Good, D.A., Wake, D.B., 1993. Systematics studies of the Costa Rican moss salamanders, genus Nototriton, with descriptions of three new species. Herpetol. Monogr. 7, 131-159.

Guillou, H., Carracedo, J.C., Torrado, F.P., Badiola, E.R., 1996. K-Ar ages and magnetic stratigraphy of a hotspot-induced, fast grown oceanic island: El Hierro, Canary Islands. J. Volcanol. Geotherm. Res. 73, 141-155.

Guindon, S., Gascuel, O., 2003. A simple, fast, and accurate algorithm to estimate large phylogenies by maximum likelihood. Syst. Biol. 52, 696-704. 
Harris, D.J., 2002. Reassessment of comparative genetic distance in reptiles from the mitochondrial cytochrome $b$ gene. Herpetol. J. 12, $85-87$.

Harris, D.J., Batista, V., Carretero, M.A., 2004. Assessment of genetic diversity within Acanthodactylus erythrurus (Reptilia: Lacertidae) in Morocco and the Iberian Peninsula using mitochondrial DNA sequence data. Amphibia-Reptilia 25, 227-232.

Harris, D.J., Carranza, S., Arnold, E.N., Pinho, C., Ferrand, N., 2002. Complex biogeographical distribution of genetic variation within Podarcis Wall lizards across the Strait of Gibraltar. J. Biogeogr. 29, 1-6.

Hsü, K.J., Montadert, L., Bernoulli, D., Bianca, C.M., Erickson, A., Garrison, R.E., Kidd, R.B., Mèliéres, F., Müller, C., Wright, R., 1977. History of the Mediterranean salinity crisis. Nature 267, 399-403.

Hsü, K.J., Ryan, W.B.F., Bianca, C.M., 1973. Late Miocene desiccation of the Mediterranean. Nature 242, 240-244.

Hudson, R.R., 2000. A new statistic for detecting genetic differentiation. Genetics 155, 2011-2014.

Hueso, F.A., 1997. Biometría, folidosis y esqueletocronología de la culebra bastarda (Malpolon monspessulanus Hermann, 1804) en Extremadura. MSc. thesis: University of Extremadura, Badajoz, Spain.

Juan, C., Emerson, B.C., Oromi, P., Godfrey, M.H., 2000. Colonization and diversification: towards a phylogeographic synthesis for the Canary Islands. TREE 15, 104-109.

Kelly, C.M.R., Barker, N.P., Villet, M.H., 2003. Phylogenetics of advanced snakes (Caenophidia) based on four mitochondrial genes. Syst. Biol. 52, 439-459.

Kocher, T.D., Thomas, W.K., Meyer, A., Edwards, S.V., Paabo, S., Villablanca, F.X., Wilson, A.C., 1989. Dynamics of mitochondrial DNA evolution in animals: amplification and sequencing with conserved primers. Proc. Natl. Acad. Sci. USA 86, 6196-6200.

Krijgsman, W., Hilgen, F.J., Raffi, I., Sierro, F.J., Wilson, D.S., 1999. Chronology, causes and progression of the Messinian salinity crisis. Nature, 652-654.

Lenk, P., Fritz, U., Joger, U., Wink, M., 1999. Mitochondrial phylogeography of the European pond turtle, Emys orbicularis (Linnaeus 1758). Mol. Ecol. 8, 1911-1922.

López-Martínez, N., Sanchiz, B., 1981. Notas sobre los microvertebrados del yacimiento arqueológico de Pontones, Jaén. Trabajos de Prehistoria 38, 134-138.

Maca-Meyer, N., Carranza, S., Rando, J.C., Arnold, E.N., Cabrera, V.M., 2003. Status and relationships of the extinct giant Canary Island Gallotia goliath (Reptilia: Lacertidae), assessed using ancient mtDNA from its mummified remains. Biol. J. Linn. Soc. 80, 659-670.

IHMCadiz 1998. Carta del Estrecho de Gibraltar. Instituto Hidrografico de la Marina, Cadiz, Spain. <http://www.armada.mde.es/ihm/Presentacion/presp/IHM_P_Main.htm>.

Martínez-Solano, I., 2004. Phylogeography of Iberian Discoglossus (Anura: Discoglossidae). J. Zool. Syst. Evol. Res. 42, 298-305.

Martínez-Solano, I., Goncalves, H.A., Arntzen, J.W., García-París, M., 2004. Phylogenetic relationships and biogeography of midwife toads (Discoglossidae: Alytes). J. Biogeogr. 31, 603-618.

Nagy, Z.T., Lawson, R., Joger, U., Wink, M., 2004. Molecular systematics of racers, whipsnakes and relatives (Reptilia: Colubridae) using mitochondrial and nuclear markers. J. Zool. Syst. Evol. Res. 42, 223-233.

Palumbi, S.R., 1996. The polymerase chain reaction. In: Hillis, D., Moritz, C., and Mable, B.K. (Eds.), Molecular Systematics. Sinauer Associates, Sunderland, MA, pp. 205-247.

Paulo, O.S., Pinto, I., Bruford, M.W., Jordan, W.C., Nichols, R.A., 2002. The double origin of lberian peninsular chameleons. Biol. J. Linn. Soc. $75,1-7$.

Pinho, C., Ferrand, N., Harris, D.J., 2006. Reexamination of the Iberian and North African Podarcis (Squamata: Lacertidae) phylogeny based on increased mitochondrial DNA sequencing. Mol. Phylogenet. Evol. $38,266-273$.
Pleguezuelos, J.M., 1998a. Malpolon monspessulanus. In: Salvador, A.(Coord.), Ramos, M.A., et al. (Eds.), Fauna Iberica. Museo Nacional de Ciencias Naturales-CSIC, Madrid, pp. 408-426.

Pleguezuelos, J.M., 1998b. Coluber hippocrepis Linnaeus, 1758. In: Salvador, A.(Coord.), Ramos, M.A., et al. (Eds.), Fauna Iberica. Museo Nacional de Ciencias Naturales-CSIC, Madrid, pp. 390-407.

Pleguezuelos, J.M., Fahd, S., 2004. Body size, diet and reproductive ecology of Coluber hippocrepis in the Rif (Northern Morocco). Amphibia-Reptilia 25, 287-302.

Pleguezuelos, J.M., Feriche, M., 1999. Reproductive ecology of the horseshoe whip snake, Coluber hippocrepis, in the Southeast of the Iberian Peninsula. J. Herpetol. 33, 202-207.

Pleguezuelos, J.M., Feriche, M., in press. Reproductive ecology of a Mediterranean ratsnake, the ladder snake Rhinechis scalaris (Schniz, 1822). Herpetol. J.

Plötner, J., 1998. Genetic diversity in mitochondrial 12S rDNA of western Palearctic water frogs (Anura, Ranidae) and implications for their systematics. J. Zool. Syst. Evol. Res. 36, 191-201.

Posada, D., Crandall, K., 1998. MODELTEST: testing the model of DNA substitution. Bioinformatics 14, 817-818.

Posada, D., Crandall, K., 2001. Intraspecific gene genealogies: trees grafting into networks. TREE 16, 37-45.

Rogers, A.R., 1995. Genetic evidence for a Pleistocene population explosion. Evolution 49, 1280-1283.

Rogers, A.R., Harpending, H., 1992. Population growth makes waves in the distribution of pairwise genetic differences. Mol. Biol. Evol. 9, 552569 .

Rozas, J., Sánchez-DelBarrio, J.C., Messeguer, X., Rozas, R., 2003. DnaSP, DNA polymorphism analyses by the coalescent and other methods. Bioinformatics 18, 2496-2497.

Saint-Girons, H., 1982. Reproductive cycles of male snakes and their relationships with climate and female reproductive cycles. Herpetologica $38,5-16$.

Schneider, S., Excoffier, L., 1999. Estimation of past demographic parameters form the distribution of pairwise differences when the mutation rates vary among sites: application to human mitochondrial DNA. Genetics 152, 1079-1089.

Schneider, S., Roessli, D., Excoffier, L., 2000. ARLEQUIN. A software for population genetics data analysis, version 2.000. Genetics and Biometry Laboratory, Department of Anthropology, University of Geneva, Geneva.

Swofford, D.L., 1998. PAUP*: phylogenetic analysis using parsimony (and other methods), v 4.0. Sinauer Associates, Sunderland, MA

Szyndlar, Z., 1988. Two new extinct species of the genera Malpolon and Vipera (Reptilia, Serpentes) from the Pliocene of Layna (Spain). Acta Zool. Cracov. 31, 687-706.

Szyndlar, Z., 1991. A review of Neogene and Quaternary snakes of Central and East Europe. Est. Geol. 47, 237-266.

Szyndlar, Z., 2000. The snakes (Reptilia, Serpentes) of the Miocene of Portugal. Ciencias da Terra 14, 359-364.

Szyndlar, Z., Rage, J.C., 1990. West Palearctic cobras of the genus Naja (Serpentes: Elapidae): interrelationships among extinct and extant species. Amphibia-Reptilia 11, 385-400.

Szyndlar, Z., Schleich, H.H., 1994. Two species of the genus Eryx (Serpentes; Boidae; Erycinae) from the Spanish Neogene with comments on the past distribution of the genus in Europe. Amphibia-Reptilia 15, 233-248.

Tajima, F., 1989. Statistical method for testing the neutral mutation hypothesis by DNA polymorphism. Genetics $123,585-595$.

Templeton, A.R., Crandall, K.A., Sing, C.F., 1992. A cladistic analysis of phenotypic associations with haplotypes inferred from restriction endonuclease mapping and DNA sequence data. III. Cladogram estimation. Genetics 132, 619-633.

Thompson, J.D., Gibson, T.J., Plewniak, F., Jeanmourgin, F., Higgins, D.G., 1997. The clustalX windows interface: flexible strategies for multiple sequence alignment aided by quality analysis tools. Nucleic Acid Res. 24, 4876-4882. 
Utiger, U., 2002. Molecular evolution and phylogenetic relationships of ratsnakes and racers (Serpentes: Colubridae). Ph.D. Thesis: Mathematisch-naturwissenschaftlichen Fakultat. Universitat Zurich, Zurich.
Utiger, U., Helfenberger, N., Schätti, B., Schmidt, C., Ruf, M., Ziswiler, V., 2002. Molecular systematics and phylogeny of old and new world ratsnakes, Elaphe AUCT., and related genera (Reptilia, Squamata, Colubridae). Rus. J. Herpetol. 9 (2), 105-124. 